\title{
Civilización y Barbarie en el Desarrollo del Teatro Nacional Rioplatense
}

$\mathrm{U}$ No de los tipos populares más característicos del Continente Americano del Sur es el gaucho, personaje que ha inspirado múltiples y geniales obras literarias en todos los géneros, desde la crónica hasta la poesía, desde el ensayo hasta la obra teatral y la novela.

El origen del gaucho es extremadamente modesto, desde el punto de vista moral, de suerte que no lo reconoceríamos después de la lectura de Santos Vega, de Martín Fierro, de Juan Moreira, de Don Segundo Sombra, de El gaucho Florido. "En realidad, el gaucho propiamente dicho, nació matrero, ${ }^{1}$ y sólo por excepción se transformó en hombre útil, en peón de estancia o en paisano trabajador. Originariamente no hubo gaucho que no fuera holgazán $y$, en algunos casos, guitarrero, bailarín y cantor". 2

El autor de esta última cita resume, sin duda, una página llena de colorido de El lazarillo de ciegos caminantes, 1775 ó 1776 , del español Alonso Carrió de la Vandera (s. Xviri), crónica atribuida a Concolorcorvo (Calixto Bustamante, Carlos Inca), ${ }^{3}$ que presenta al gaucho como producto genuino de la generosa tierra americana. "De esta propia abun-

11 "Se llamaba matyero al gaucho que andaba huyendo de la jusitcia por haber cometido algún delito: un crimen, un robo, etc., o simplemente por rebelarse contra la prepotencia de algunas autoridades. El matrero se escondía en los pajonales y en los montes, de preferencia, y como contaba con la ayuda de la mayor parte de los pobladores, por simpatía unos, por miedo otros, a la policía le resultaba casi imposible tomarlo preso". Pedro Inchauspe. Voces y costumbres en el campo argentino. Ilustraciones de Juan Hohmann. $2^{2}$ edición. Buenos Aires: Ediciones Colmegna, 1949, p. 195.

2 Domingo F. Casadevall. El tema de la mala vida en el teatro nacional. Buenos Aires: Ed. Guillermo Kraft, Limitada, 1957, p. 25.

3 Sobre el autor de El lazarillo de ciegos caminantes, véase: Marcel Ba. taillon. "Introducción a Concolorcorvo y a su itinerario de Buenos Aires a Lima". Cuadernos Americanos, México, D. F., año XIX, vol. CXI, ${ }^{\circ} 4$, junioagosto, 1960 , p. 197-216. 
dancia, como dije arriba, resulta la multitud de holgazanes a quien con tanta propiedad llaman gauderios. Son estos mozos nacidos en Montevideo y en los vecinos pagos". La larga descripción del gaucho que se consigna en la crónica, incide principalmente en afirmar, además de su holgazanería, su extremado amor a la libertad más desenvuelta que le brinda la pampa. "Se pasean a su albedrío por la campaña y con notable complacencia de aquellos semibárbaros colonos, comen a su costa y pasan las semanas enteras tendidos sobre un cuero, cantando y tocando"."

En tales condiciones de vida sin apremios, era natural que, con el tiempo, el gaucho llegara a constituirse en un individuo antagónico a cualquier régimen que pretendiera establecer un orden social riguroso. Era temido y perseguido por las fuerzas de orden. La pampa pródiga y abierta fue siendo objeto de propiedad privada, sus productos controlados y sus horizontes cada vez más vigilados. El gaucho fue acorralado y ya no le quedaron más que dos caminos: aceptar las penurias de los cuerpos de línea que guardaban la frontera o convertirse en gaucho malo o matrero, ${ }^{5}$ suerte que corrió Martín Fierro. "La partida rara vez lo sigue; mataría inútilmente sus caballos, porque el que monta el gaucho malo es un parejero pangaré tan célebre como su amo. Si el caso to echa alguna vez de improviso entre las garras de la justicia, acomete a lo más espeso de la partida, y a merced de cuatro tajadas que con su cuchillo ha abierto en la cara de los soldados, se hace paso entre ellos, y tendiéndose sobre el lomo del caballo, para sustraerse a la acción de las balas que lo persiguen, endilga hacia el desierto...". ${ }^{6}$ En una riña, "si sucede una desgracid, las simpatías están por el que se desgració; el mejor caballo le sirve para salvarse a parajes lejanos, y alli lo acoge el respeto o la compasión. Si la justicia le da alcance, no es raro que le hga frente, y si corre a la patitida, adquiere un renombre desde entonces, que se dilata sobre una ancha circunferencia. Transcurre el tiempo, el juez se ha mudado, y ya puede presentarse de nuevo en su pago sin que se proceda a ulteriores persecuciones; está absuelto. Matar es una desgracia, a menos que el hecho se repita tantas veces, que inspire horror el contacto del asesino". 7

4 Concolorcorvo, El lazarillo de ciegos caminantes, Madrid: Ediciones Atlas [Colección Cisnetos, $\mathrm{n}^{\circ} 23$ ], 1943, p. 25 .

5 Juan Carlos Ghiano, Teatra gauchesco primitivo. Prólogo a Juan Moreira, de Eduardo Gutiérrez-José J. Podestá. Buenos Aires: Ediciones Losange [Colección Teatro Argentino, $\mathrm{n}^{\circ}$. 1], 1957, p. 98.

6 D. F. Sarmiento, Civilización y barbarie, Buenos Aires: Félix Lajouane, editor, 1889, p. 43-44 [La primera edición es de Valparaíso (Chile), 1845].

7 Sarmiento, ob. cit., D. 50. 
Este hombre semibárbaro, de largos cabellos y barba hirsuta, con su caballo y su facón, siempre rebelde a todo sistema que coarte su libertad, hostil al trabajo productivo, foragido sin ley cuando las circunstancias lo arrastran a ello, que ponía su cuchillo al servicio de los caciques políticos, y que tiene la gracia innata del canto y la poesía, comienza un largo proceso de dignificación en la literatura, con las luchas contra la invasión inglesa de 1806 , luego en la Revolución de 1810 , y la Guerra Gaucha (I8I4-I8I8), momentos en que dio muestras de sentido de patria y comprensión de los ideales de independencia y democracia, cuando algunos porteños vacilaban. ${ }^{8}$ Así aparece en los Cielitos, r81 I-18r6, de Bartolomé Hidalgo ( 1788 -1822), y luego en los Dialogos patrióticos, 182I-1822, del mismo poeta gauchesco, el primero en comprender el valor del lenguaje de los payadores como eficaz vehículo de comunicación entre los patriotas. Pero el gaucho se presenta con todas sus virtudes y todos sus defectos en Civilizactón y barbarie, 1845, de Domingo Faustino Sarmiento (r8rr-r888). Este libro, que sigue asombrando al mundo por su vigor $y$ colorido, es, sin duda, la fuente primordial de toda la progenie de la literatura gauchesca de corte romántico, en que se idealiza al personaje, ya como cantor, ya como perseguido, ya como hombre de bien, aunque vagabundo. Primero va a ser el gaucho Amaro de Caramumi, novela histórica, publicada en Madrid, en $\mathrm{i} 848$, del romántico uruguayo Alejandro Magariños Cervantes (1825-I893). En seguida, Santos Vega o Los Mellizos de La Flon, $185 x$ y 1872 , de Hilario As. casubi ( $1807-1875$ ); le siguen Fausto, I866, de Estanislao del Campo (1834-1880); Los tres gauchos orientales y el matrero Luciano Santos, I872, del uruguayo Antonio D. Lussich; Martín Fierro, I872 y I879, de José Hernández (1834-1886); Juan Mareira, r879, novela folletinesca, de Eduardo Gutiérrez (1853-I890); Santos Vega, poema gauchesco, en Poesias, I885, de Rafael Obligado (I85I-1920); Juan Moreira, 1896, drama, en dos actos y doce cuadros, de Eduardo Gutiérrez-José J. Podestá; Don Segundo Sombna, 1926, novela de Ricardo Güiraldes (1886r829); Los cuentos de Javier de Viana (.x68-I926).

En esta nómina omitimos, deliberadamente, obras gauchescas que es. tudiamos más adelante, y otras que - como los cuentos de Roberto J. Payró, Los carancbos de la Florida, I916, de Benito Lynch (1880-1952) y Coirón, tierra de los borizontes stmergidos, I950, novela del chileno

8 Enrique Anderson-Imbert, Historia de la literatura bispanoamericana, I. La Colonia. Cien años de República (3ra. edición), México: Fondo de Cultura Económicas, 1961, p. 202. 
Daniel Belmar (r906) - - caen dentro de un realismo crítico muy ajeno al gauchismo romántico que diseñamos.

Juan Moreira es la dramaitzación de una de las treinta novelas de carácter folletinesco y truculento que escribió el argentino Eduardo Gutiérrez, publicada en La Patria Argentina, desde noviembre de 1879 hasta enero de r880. Gutiérrez se inspiró en un caso real, un gaucho delincuente que, por el año 1870 , según consta en documentos judiciales," operaba como matón a sueldo de caudillos políticos nada escrupulosos, y que el novelista transformó en héroe popular, al modo de Martín Fierro.

En 1884, el actor uruguayo José J. Podestá (I858-1936), cogió el tema y compuso un pantomima para el circo de los Hermanos Carlo, que funcionaba en el Politeama Argentino. "Todo se acompañaba con mímica, acompañada de música apropiada-dice Podestá en sus Memortas-; sólo el Gato con relaciones y el Estilo que cantaba Morcira en la fiesta campestre, interrumpía el mutismo de los actores".

Luego, en $\mathrm{r} 886$, por recomendación de uno de los espectadores del mimodrama, ${ }^{10}$ que vio las enormes posibilidades escénicas de la pieza, José J. Podestá puso diálogo al tema, aprovechando, naturalmente, el texto literario de la novela de Eduardo Gutiérrez. De allí resultó el drama en dos actos y doce cuadros, en prosa, Juan Moreira, ${ }^{\text {th }}$ que se

9 Juan Alvarez, "La actuación de Juan Moreira juzgada por la Cámara de Diputados", La Prensa, Buenos Aires, 18 de mayo de 1927 y 19 de junio de 1927. José J. Podestá, Medio siglo de farándula, Memorias, Río de la Plata (Cordoba), 1930. Enrique García Velloso, Memorias de un bombre de teatro, Buenos Aires, Ed. Guillermo Kraft, 1942, vid.: "Eduardo Gutiérrez y la verdad sobre Juan Moreira". Nerio Rojas, "El verdadero Juan Moreira", Boletin de Estudios de Teatro, junio de 1943. M. E. L. (Marcos de Estrada), Juan Moreira, Realidad y mito. Buenos Aires: Imprenta López, 1956. Rubén A. Benítez. Una bistórica función de circo, Universidad de Buenos Aires, Departamento Editorial, 1957. Para las actividades teatrales en Chiarilcoy antes de la representación de Juan Moreira, véase: Alfredo A. Roggiano, Una obra desconocida del teatro bis. panoamericano... State University of Iowa, 1958.

10 Hallábase el Circo Podestá-Scotti en Arrecifes. El señor León Beaupuy, un francés emigrado, de cierta cultura y gusto artístico, felicitó a Podestá por el espectáculo, y agregó: " con el gesto y la mímica. Este drama hablado llanamente, adquiriría una fuerza emotiva comparable a la que producen las grandes concepciones clásicas, hechas con vistas a la humanidad antes que a la literatura. El dia que ustedes hablen este drama, habrán realizado una de las más ponderables obras teatrales que yo conozco, $y$ he visto muchas en mi París del alma!" (Citado por Enrique García Velloso, en "Los primeros dramas en los circos criollos". Cuademos de Cultura Teatral, $\mathrm{n}^{8}$ 2, del Instituto Nacional de Estudios de. Teatro, Buenos Aires, 1936, pp. 60-63.

11. El manuscrito de Podestá se conserva en el fondo bibliográfico del Ins. tituto de Literatura Argentina, de la Universidad de Buenos Aires Este organismo publicó la obra en la sección Documentos, Tomo VI, $\pi^{\circ} 1$, en 1935, con una introducción, escrita por Carlos Vega, y algunos pasajes de las Memorias, de 
estrenó en Chivilcoy, el ro de abril de 1886. Después' de algunas funciones en provincia, la obra es llevada a Buenos Aires, donde fue recibida con clamoroso aplauso.

El argumento resume las contingencias que tradicionalmente acaecen al gaucho matrero. El modelo estructural está dado en Martín Fierro, cuya primera parte aparece siete años antes que la novela de Gutiérrez:

$Y$ sepan cuantos escuchan

de mis penas el relato

que nunca peleo ni mato

sino por necesidá

y que a tanta alversidá

sólo me arrojó el maltrato.

$Y$ atiendan la relación

que hace un gaucho perseguido,

que padre y marido ha sido

empeñoso y diligente,

y sin embargo la gente

lo tiene por un bandido.

(El gaucbo Matrin Fierro, La Ida, canto $I$, estrofas 18 y $\mathrm{I}_{9}$ ).

Juan Moreira es un paisano honrado, vive con su mujer, Vicenta, su. hijo Juancito y su suegro, el Tata viejo. Ha prestado, hace algún tiempo, diez mil pesos al pulpero Sardetti, dinero que ahora necesita y reclama; como Sardetti se niega a devolvérselo, acude al despacho del alcalde, don Francisco; allí el pulpero sigue negando la deuda; el funcionario da crédito al "gringo" y hace castigar ominosamente al gaucho, en el cepo. En la primera ocasión que se presenta, Moreira da muerte, "en buena ley" a Sardetti, y huye. Ahí comienza lo más duro de sus desventuras. Es perseguido; debe esconderse y, a veces, hacer frente a la partida, matando a unos, hiriendo a otros y dispersando a los demás. Con ello, su fama se extiende por todas partes. Un dia vuelve al pago, entra a la oficina del alcalde, y salda su cuenta de sangre con él.

Su buen corazón, no obstante, se muestra al comienzo del acto II,

José J. Podestá. Otra edición: Teatro gauchesco primitivo, Buenos Aires: Ediciones Losange [Colección. Teatro Argentino, $\mathbf{n}^{9} 1$, dirigida por Juan Carlos Ghiano], 1957. 
cuando salva al político Marañón de ser asesinado. Por su amigo Julián ha sabido que su compadre Giménez lo ha traicionado; ha hecho creer a Vicenta, quien se debate en la miseria, que Moreira ha muerto y que debe aceptar su ayuda para poder subsistir. El gaucho llega sorpresivamente a su casa, dispuesto a vengar la afrenta, pero Giménez se escapa. Moreira se va definitivamente de su pago. Después de otro encuentro con la partida, Moreira y Julián descansan en un burdel, donde son atrapados por la policía. Toman a Julián, y Moreira se defiende, peleando con salvaje bravura contra los soldados. En los momentos en que va a saltar una tapia, el soldado Chirino lo clava con una bayoneta, por la espalda. Esta última escena de la muerte de Moreira, carece de diálogo escrito, y los actores deben improvisar, en medio de la agitada acción.

El drama está dotado de todos los elementos que halagan el sentimiento y el gusto populares. "Era frecuente en el interior del país la prepotencia de caudillos políticos y de las autoridades policiales obsecuentes que cometían desmanes, atropellos e injusticias. En este sentido, el folletín de Gutiérrez es un documento más, un documento realista, como lo fueron antes el Martin Fiemo, de Hernández, y posteriormente, los cuentos de Pago Cbico, de Roberto Payró o las novelas de Carlos M. Ocantos".12

Juan Moreira aparece como el gaucho valiente, honrado, que se revela contra las injusticias de los tiranuelos locales, que abusan de su autoridad y hasta intentan seducirle a su mujer. Muestra su alma generosa, cuando presta ayuda desinteresada al paisano en peligro y pelea $y$ ahuyenta a la partida que lo persigue injustamente (Idem.).

Está insinuada, además, la nota del favoritismo de las autoridades por el extranjero emigrado, elemento que va a constituir un motivo importante en el teatro argentino posterior.

Ezequiel Martínez Estrada no está de acuerdo en que la obra represente un estado social profundo. Según su criterio, Juan Moreira "reemplazó la injusticia social, el desorden gubernamental, con la injusticia personal del funcionario, la mala política con el mal político, la causa verdadera, con sus agentes ejecutivos".13

Lo más notable del montaje escénico era el hecho que se representara en dos terrenos: en la pista del circo, lo que permitía amplias

12 Raúl H. Castagnino, Esquema de la literatura dramática argentina (1717. 1949), Buenos Aires: Instituto de Historia del Teatro Hispanoamericano, Talleres Gráficos "El Progreso", de Juan P. Castagnola e Hijo, 1950, p. 62.

13 Ezequiel Martínez Estrada, Muerte y transfiguración de Matrín Fierro, Ensayo de interpretación de la vida argentina, México-Buenos Aires: Fondo de Cultura Económica, 1948 (Tomo II, p. 483). 
evoluciones a caballo y otras acciones propias de los exteriores, de imposible ejecución en un tablado, y en un escenario armado para escenas interiores o en que se requería un decorado más estricto. Así, las fiestas campestres y aquéllas que requerían espacio y la presencia de la pampa, se practicaban en la arena; en cambio, la despedida del gaucho de Vicenta, su hijo y el Tata viejo, ocurre en el escenario; igualmente la muerte de Moreira acorralado en el burdel de "La Estrella".

Este riquísimo juego escénico exigía un tratamiento de iluminación bastante complejo, que a fines del siglo pasado todavía no era posible obtener. En I958, la Compañía de Francisco Petrone estrenó en el Citco Teatro-Arena, una versión de la obra, con el título de La leyenda de Juan Moreira, con diálogo de Rodolfo Kusch y poesía de Goly Bernal. ${ }^{14}$ Esta nueva versión tiene catorce cuadros, y un tratamiento más variado que el drama primitivo; pero en esa fecha se cuenta con recursos luminográficos más completos y eficaces para resolver cualquier problema técnico.

Sin embargo, el espectáculo de Podestá debió ser indudablemente, lleno de interés y colorido, por la combinación de teatro y circo, con lo que se rompian todas las normas del arte escénico tradicional. En lo estrictamente circense no hay verdadero teatro, porque no hay represeritacion, esto es, no se dice o se hace algo por cuenta de otro (el autor), sino que se lucen habilidades personales, como ocurre con el trapecista o la equitadora; en el circo, los únicos que hacen teatro propiamente tal, son los "tonis". 15 En el Juan Moreira, se exhiben destrezas indidividuales, como los ejercicios ecuestres, las payadas y las acciones de esgrima, al mismo tiempo que se representan tipos y se crean situaciones escénicas. Esta novedad fue, sin duda, lo que inquietó tan hondamente a Mr. León Beaupuy, cuando recomendó poner letra al mimodrama.

Desde el punto de vista literario, la obra es esquemática y débil. No hay que olvidar que José J. Podestá, el adaptador, no era escritor; su oficio era el de cómico, campo en el que descolló brillantemente, sobre todo en la interpretación de gauchos de recia contextura, como Moreira y otros. Por otro lado, Eduardo Gutiérrez era, ante todo, narrador, cuya técnica, analítica y demorada, tanto se contrapone a la apretada sintesis del teatro; además, Gutiérrez jamás se interesó por el gé-

14 Rodolfo Kusch, La muerte del Chacbo. La leyenda de Juan Moreira, con poesía de Goly Bernal, Buenos Aires: Ed. Stilcograf, 1960.

I5 Galina Tolmacheva, Creadores del Teatro Moderno, Buenos Aires: Ediciones Centurión, Librería Hachette, S. A. [Colección Arte], 1949, p. 17. 
nero dramático; ni siquiera intervino en la adaptación escénica de su novela; y lo que es más decidor aún, nunca vio una representación de la pieza. ${ }^{16}$

Todas estas circunstancias, incluyendo la forma circense de este primer espectáculo nacional argentino, ha suscitado controversia y ha dividido las opiniones en dos bandos antgónicos: unos que niegan a Juan Moreira su categoría de punto de partida del teatro nacional moderno de Argentina, y otros que sostienen, entusiastamente, lo contrario.

El primer criterio, de riguroso esteticismo, puede resumirse en las palabras del profesor Carlos B. Quiroga, que afirma: ". Juan Moreira no tiene la categoría estética suficiente para ser considerada como una verdadera obra de arte, por consiguiente, considero equivocados a los que piensan que el teatro nacional se forma y se produce con la representación de Juan Moreira".17

Mariano G. Bosch, el decano de los investigadores sobre el teatro argentino, sostiene: "Si hemos de entender por obra de teatro nacional argentino aquella que por su asunto, sus personajes y su ambiente es realmente argentina, podremos afirmar con toda verdad que la primera que subió a las tablas de nuestro teatro fue la de Ambrosio Morante, el 24 de mayo de 18 I2, y que se titulaba $E l 25$ de mayo. Y en esto también dejamos establecido que el fundador del teatro nacional es él". ${ }^{18}$ Es del caso recordar, sin embargo, que Luis Ambrosio Morante es peruano, y su aliento llena la actividad teatral de Buenos Aires y de Santiago de Chile, durante los tres primeros decenios de aquella centuria. Juan M. Gutiérrez (r809-1878), se inclina a atribuir ese noble origen a Juan Cruz Varela (1794-I839), autor de las tragedias Dido y Argía, piezas de corte neoclásico; Dido está inspirada en el canto IV de la Eneida, de Virgilio, y Argía desarrolla un tema ubicado en una época anterior a la guerra de Troya.

Dentro de este grupo figuran nombres de tanta notoriedad, como

16 De una carta escrita por José J. Podestá a Enrique García Velloso, algunas de cuyas frases cita éste último, en "Los primeros dramas en los circos criollos", ya citado. El mismo García Velloso hace referencia a los apuntes de Fray Mocho (José Zeferino Alvarez, 1858-1903), coetáneo y amigo de Gutiérrez, en que revela que el novelista nunca se interesó por sus propias obras literarias, que escribia sin corregir, y sólo para ganarse la vida.

37 Carlos B. Quiroga, "Aparición y formación del teatro nacional; cómo deben presentarse sus características regionales", Cuadernos de Cultura Teatral, Instituto Nacional de Estudios de Teatro, Buenos Aires, $\mathrm{n}^{9}$ 17, 1942, p. 17.

18 Mariano G. Bosch, "Los origenes del teatro nacional argentino", conferencia pronunciada el 24 de agosto de 1936, Cuadernos de Cultura Teatral, Instituto Nacional de Estudios de Teatro, Buenos Aires, $\mathrm{n}^{\circ} 1$, 1936, pp. 65-67. 
Ricardo Rojas, el primero que rebatió a los moreiristas, y Jorge Max Rohde.19

Otros hay que, a regañadientes, se ven obligados acatar el peso incontrastable de la obra gauchesca, como es el caso de Martín García Mérou (I862-I905). All reconocer este ensayista los esfuerzos de algunos grupos intelectuales por instituir oficialmente una literatura dramática vernácula (el Circulo Científico Literario y la Academia Argentina), escribe: "Ha pasado una década y el problema insoluble del teatro nacional ha sido resuelto por un payaso con instinto y temperamento de actor, que ha transformado la insulsa pantomima de su circo en una serie de cuadros dramáticos que retratan la vida de un bandido legendario. Como un supremo sarcasmo a la inteligencia y al arte, Juan Moretra ha logrado lo que no pudo conseguir Coronado, con La Rosa Blanca o Luz de luna y luz de incendio". 20

Los que aclaman la pieza de Podestá-Gutiérrez, forman también por su parte, un grupo brillante. Uno de los primeros en reconocer su categoría de hito, es Florencio Sánchez, el continuador de la tradición gauchesca y en quien culmina esa temática. El autor de M'bijo el dotor afirma en una conferencia: "Es cosa averiguada que el actual teatro rioplatense nació en la pista de un circo, al amparo que le dio una compañía de acróbatas transhumantes". Y luego: "...proceden a la ligera quienes desdeñan, por inferior, esta paternidad cierta y van a buscarle a nuestro teatro más altos y nobles orígenes en las tragedias pseudoclásicas de Labardén y Varela. ${ }^{21}$

Por su parte, Roberto F. Giusti, en una conferencia dictada en 1937, en Buenos Aires, dice: "Me encuentro entre los primeros que señalaron la influencia capital del drama Juan Moreira. No hay que avergonzarse de este nacimiento plebeyo. Más que populares fueron los origenes de todos los teatros".

En este recuento, es preciso consignar que hay quienes piensan que el verdadero iniciador del teatro nacional rioplatense es Florencio Sánchez con M'bijo el dotor, I903; tal criterio es sustentado por el ensayista uruguayo Alberto Zum-Felde. ${ }^{22}$

19 Ricardo Rojas, "Los gauchescos", en Literatura Argentina, Buenos Aires: Librería La Facultad, Juan Roldán y Cia., 1925. Jorge Max Rohde, Las ideas estéticas de la literatura argentina (4 tomos), Buenos Aires: Casa Editora Coni, 1921-1926.

פo Martín García Mérou, Recuerdos Literarios, con una introducción de Ricardo Monner Sans, Buenos Aires: "La Cultura Argentina", 1915, p. 266.

21 Florencio Sánchez "El teatro nacional", conferencia publicada en Bambalinas, revista teatral, Buenos Aires, año IV, n⿳亠口冋 146, 22 de enero de 1921.

$₫$ Alberto Zum-Felde, Proceso intelectual del Uruguay y critica de su li- 
En todo caso, la representación de esta obra tuvo la virtud de probar que se podía escribir excelente teatro con los temas populares vernáculos; al mismo tiempo estableció la existencia de buenos intérpretes nacionales y de un público ávido y alentador.

Descubierto el tema gauchesco en el teatro, surgen otros cultivadores inmediatos, como los uruguayos Elías Regules (I860-1929), Orosmán Motatorio (1852-1898) y Víctor Pérez Petit (I871-I946).

Pero la línea gauchesca primaria adquiere un nuevo matiz con $\mathrm{Ca}$ londria, del argentino Martiniano Leguizamón (1858-1935), obra estrenada el 21 de mayo de 1896, por los mismos intérpretes del Moreina, que ahora se ven exigidos por una obra de verdadera categoría teatral, cuyos apremios histriónicos superan exitosamente. "Calandria es la obra más representativa de la época - sostiene Luis Ordaz--, y tiene a su vez el extraño valor de ser la llave con la cual los Podestá pudieron trasponer las pucrtas de un teatro"..$^{23}$

Calandria, nombte de un ave pequeña y que no puede vivir enjaulada, de armonioso canto, es el apodo de un gaucho, como Juan Moreira, pero más noble y cantor, más fino y de rasgos más humanos. Calandria difiere del Moreira en que la justicia lo persigue por faltas de poca monta, y él la combate, no ya con la fuerza y el facón, sino con la inteligencia, con recursos de liviana picardía, que superan, estéticamente, el heroísmo sanguinario y truculento de Moreira. Por otra parte, la obra tiene una salida optimista, porque su personaje termina por integrarse a la sociedad como un factor positivo, con to cual el autor llama la atención hacia la necesidad de comprender el problema del gaucho en sus verdaderos términos: el gaucho es un elemento valioso, cuando se le brindan las condiciones de adaptación a la convivencia y al trabajo productivo. ${ }^{24}$

La obra de Leguizamón abre, pues, el horizonte del gaucho tradícional; comienza la era de su domesticación y, consecuentemente, de su dignificación. Ha quedado atrás el gaucho holgazán y bárbaro de $E l$ lazarillo de ciegos caminantes, el fatal y trágico Martín Fierro, el doliente Santos Vega y el sanguinario Moreira.

Este matiz meliorativo del gaucho se intensifica en La piedrat de es-

teratura, Montevideo: Imprenta Nacional Colorada, 1930. Otra edición, Montevideo: Editorial Clatidad, 1941.

23 Luis Ordaz, El teatro en el Río de la Plata. Desde sus origenes basta nuestros dias, $2^{7}$ edición, corregida y aumentada, Buenos Aires, Ediciones Leviatán, 1957 , pp. 46-47.

224 Julio A. Leguizamón, Historia de la literatura bispanoamericana, tomo II, Buenos Aires: Editoriales Reunidas, S. A., Argentina, 1945, p. 221. 
cándalo, drama en verso, estrenado el I6 de junio de I902, de Martín Coronado (1850-19r9), ${ }^{25}$ la obra criolla de mayor resonancia de la época, también inetrpretada por los hermanos Podestá.

Martin Coronado habia producido otras piezas teatrales, con anterioridad, como La Rosa Blanca, ya citada, 1877; Bajo la Tirania, 1878; Salvador, I885; Cortar por lo más delgado, I893; Un soñador, I896, y Justicias de antaño, r897. Pero a pesar de sus esfuetzos por configurar una dramática nacional en estas obras, no logra su objetivo, porque se queda en lo externo y melodramático del tomanticismo desfalleciente, tomado de sus maestros españoles, de cuya férula no se va a liberar totalmente: Zorrilla, Echegaray, Francisco Camprodón.

No obstante, con La piedra de escándalo, Coronado inaugura una nueva corriente en el teatro gauchesco. Ahora hay otra visión del tipo; aparece la chacra, con gauchos sin chiripá, sin peleas con la partida, sin el pintoresquismo carnavalesco, en suma. Es gente de trabajo, con problemas familiares, económicos y amorosos; la vida en sus cauces normales.

La piedra de escándalo es Rosa, que ha vueltó al pago después de un desliz en la ciudad; su hermano Pascual es uno de los pocos que la acoge bien y la comprende; no así su hermana Leonor y sus hermanos menores, que ven en Rosa un motivo de merma en la futura herencia paterna. Las figuras de carácter de la obra son don Lorenzo, el abuelo italiano, y Pedro, el padre de Rosa.

Los antiguos trapecistas rindieron la prueba final de su capacidad interpretativa. En esta obra de Coronado, fuera de la de sonoridad y fluidez de los versos zorrilescos y de algunos efectos melodramáticos fáciles, al modo de Echegaray, no había más concesiones al público, por medio de espectáculo marginal, que eran los recursos gratos al auditorio del Monetira y Calandiria. El actor debía concretarse a su puro oficio de intérprete de un texto literatiamente elaborado y a la creación de personajes humanos, llenos de un contenido psicológico: mujeres dolidas o envidiosas o despechadas; hombres sinceramente enamorados, o ambiciosos o bondadosos o paternales. Es decir, el intérprete debía seguir al autor que comenzaba a bilar más fino en su buceo en el alma del hombre que inauguraba un siglo de creciente complejidad.

Los testimonios revelan que el público comprendió el nuevo giro que se anunciaba en el teatro argentino, a pesar de que Coronado per-

25 Obras completas ( 8 tomos), vol. III, Buenos Aires: Talleres Gráficos Argentinos de L. J. Rosso y Cía., 1925. 
manecia todavía dentro de un criollismo externo "sin que la marca nativa surja del propio conflicto o de la propia entraña de los personajes: salvo Ciriaco y ligeramente la estampa del viejo Lorenzo, aquellas figuras que visten poncho y chiripá piensan, actúan y se comportan como si llevaran la levita española de fines de siglo".26 Era el gusto general.

Una prueba de la popularidad que conquistó La piedra de escándalo con sus múltiples representaciones, a principio de siglo, es que dejó en la memoria del público la famosa décima recitada por Manuel, al comenzar el acto II:

Sobre el alero escarchao

encontré esta madrugada

una palomita helada

que el viento había extraviao.

Porque es tuya la he cuidao

con cariño y con desvelo,

y la cinta color de cielo

con que venía adornada

al cuello ia tengo atada

porque es cinta de tu pelo.

Después de producir otras piezas, Coronado estrena en marzo de 19r8, el drama La chacra de don Lorenzo, segunda parte de La piedra de escándalo, con la que el autor termina su labor teatral. ${ }^{27}$

Desde el punto de vista puramente literario, la obra más lograda y equilibrada de Martín Coronado, es el drama en cuatro actos y en verso, El sargento Palma, estrenada en el teatro Apolo, de Buenos Aires, el $x_{4}$ de mayo de 1906, por la compañía de José J. Podestá. ${ }^{28}$

En el ambiente tenso, de crueles persecuciones y extorsiones de la tiranía de Rosas, en San Pedro, Provincia de Buenos Aires, describe un tipo de federal bien intencionado y de excelente fondo humano: el sargento Palma, de la policía federal, que se deja condenar a muerte para salvar de esa misma pena capital a la mujer amada, adicta al bando unitario, y de quien no es correspondido en sus sentimientos. Magdalena,

226 Arturo Berenguer Carisomo, "Martín Coronado: Su tiempo y su obra". Conferencia pronunciada el 2 de octubre de 1939, Cuadernos de Cultura Teatral. Instituto Nacional de Estudios de Teatro, Buenos Aires, $\mathbf{n}^{9} 15,1940$, p. 20.

at Obras completas, vol. VII.

28 Obras completas, vol. IV. 
Ia unitaria, de dieciocho años, escucha las efusiones amorosas de Palma, mientras su padre, don Gregorio, libera de los calabozos del cuartel, al unitario y revolucionario don Luis; cuya custodia estaba a cargo del sargento $\mathrm{y}$ sus soldados.

Dos o tres notas de sobrecargado patriotismo relajan un tanto una construcción dramática muy bien llevada y de creciente interés. Coronado domina la difícil técnica del diálogo en verso octosílabo, sabe crear situaciones densas de emoción, resolver problemas escénicos con verosimilitud y estructurar reciamente los personajes. El sargento Palma es un ser humano cabal, ya maduto, de cuarenta y tres años, de la más auténtica extracción popular, pero de noble corazón.

Es verdad que Coronado casi siempre emplea los mismos recursos en sus diversas obras, los golpes escénicos de efecto que gustaban al público de la época, momento de búsqueda de la consolidación de una raza que se formaba afanosamente; pero esos recursos eran usados con verdadera eficacia teatral. Por ejemplo, vemos en La piedra de escandalo tanto como en El sargento Palms, que hay un personaje avieso que amenaza malograr los buenos propósitos del personaje central, $y$, por consiguiente, una escena culminante en que, puesto el conflicto entre ambos, triunfan las fuerzas del bien. Así sucede con Manuel frente al celestinesco Ciriaco, de La piedra. . , y con el sargento Palma frente al cruel y acérrimo federal sargento Tabares.

La sostenida labor teatral de Coronado, que animó los escenarios rioplatenses durante más de cuarenta años, su ductilidad para adaptarse a los cambios que iba experimentando el proceso dramático argentino y su sincero afán de hacer un teatro nacional, son méritos suficientes para conferirle el calificativo de patriarca del teatro de su país, que le han adjudicado los estudiosos de la República hermana.

El tercer dramaturgo de esa generación señera, que da forma al teatro nacional y prepara el advenimiento de Florencio Sánchez, es Nicolás Granada (1840-1915). Sólo unos meses después del ruidoso estreno de La piedra de escándalo, se estrena en el Teatro Apolo, el 26 de septiembre de ryo2, la comedia ;Al campo!, en tres actos y en prosa.

Hasta la obra de Coronado, el teatro argentino se mantenía virtualmente dentro de los cánones policiacos fijados por el Moreira. Escenas configuradas a grandes trazos y los conflictos resueltos, por 10 general, de modo rotundo. Personajes unidimensionales y un ambiente social de escasas proyecciones. Este esquematismo épico sin ahonda- 
mientos en análisis, sin matizaciones de más aguda elaboración era necesario en aquella etapa de gestación de la escena rioplatense.

Ya en Granada se van a superar esas líneas primarias. El autor manifiesta en iAl campo! - lo que va a confirmar en La gavioha- mayor perspicacia teatral y mayor conciencia del momento social de Argentina y Uruguay, dos factores altamente reveladores del nuevo rumbo que toma el arte dramático a impulsos del realismo-naturalismo ya imperante en el Contienente, a través de otros géneros. Era la salida justa que debían tener los esfuerzos de las payasos geniales.

Un bosquejo del argumento de la pieza nos dará pie para comen. tar las significaciones mencionadas.

Los personajes de mayor relieve son don Indalecio, un hacendado que ha hecho su fortuna con su trabajo, honrado, con las pocas letras que le permitió obtener su vida de acción, pero socarrón, con toda la cachaza criolla del gaucho viejo. Doña Fortunata, su esposa, mareada con la holganza que le ha dado el dinero, su mayor deseo es ostentar y hacer, en la ciudad, una vida de buena sociedad. Gilberta, hija de ambos, joven con un barniz de educación, acompaña a su madre en su prurito arribista. Gabriel, joven campesino, sano de espíritu, sin retorcimientos psicológicos ni pretensiones sociales.

Pues bien, contra todas las oposiciones de don Indalecio, su esposa y su hija, han logrado que la familia se instale a vivir en Buenos Aires, donde todos pueden participar de los refinamientos urbanos. Es entonces cuando se promueven escenas que Granada presenta con liviano sabor costumbrista, por el contraste entre el paisano y el medio citadino, por "contraposición de la natural y sana espontaneidad campestre, fiel a la tradición genuina, y la rebuscada artificiosidad del exotismo mundano, de lo advenedizo en la vida del país, que vicia el ambiente de la ciudad"..20 Aparecen los consabidos galanes que engatuzan a las nuevas ricas, ávidas de emociones inéditas, explotan sus veleidades, y pretenden estafarlas sin miramientos. Descubierto el golpe, don Indalecio hace entrar por sus fueros a las descarriadas y ordena regresar al medio del que no debieron salir en ese plan de volverle las espaldas: iAl campo!

Allí está la tierra sin falsedades, allí está Gabriel; y Gilberta comprende que en él se dan las préndas del verdadero amor. La obra termina con un augurio de trascendencia, una mirada limpia y sincera

29 Arturo Giménez Pastor, "Nicolás Granada: El hombre y su obra". Conferencia pronunciada el 25 de septiembre de 1939. Cuadernos de Cultura tea. tral. Instituto Nacional de Estudios de Teatro, $n^{\circ}$ 14, Buenos Aires, 1940, p. 117. 
al porvenir, una buena disposición al trabajo por una patria mejor, sin desconocer los valores auténticos que se ponen en juego en una nación que - ya desde fines del siglo- entra por sus hondos cauces.

El tema, aunque sencillo, requiere un tratamiento más sutil y pormenorizado que en las obras ya comentadas de los autores precedentes, y Granada construye una pieza llena de gracia y de profundas lecciones, afinando decididamente la línea definitiva del teatro rioplatense.

La búsqueda de una expresión teatral a través del gaucho que se había iniciado con el Moreira, en r886, viene a desembocar, con un arrastre de pujante maduración, en el drama en tres actos, M'bijo el dotor, estrenado el $\mathrm{I}_{3}$ de agosto de r903, de Florentino Sánchez (I875r9ro).$^{30}$ Esta obra, junto con La gringa (1904) y Barrancal abajo (I905) forman la trilogía gauchesca más notable del teatro rioplatense.

Por estas piezas y otras que comentaremos más adelante, así como por las excepcionales circunstancias de su vida, Sánchez constituye uno de los más extraordinarios casos del Continente, por lo que ocupa un egregio lugar entre los dramaturgos hispanoamericanos.

Veía su realidad en términos teatrales; tenía la intuición de la escena. "Si a la poderosa capacidad representativa de los hechos actuales - dice Ricardo Rojas, una de las categóricas voces de la cultura argen. tina - hubiera unido más amplio don de generalización filosófica para engendrar sus asuntos y más intenso numen de evocación poética para embellecer la vida de las almas, su caso hubiera sido, a no dudarlo, el de un dramaturgo genial". 31

Otro crítico especializado en materia escénica, Juan Pablo Echagüe (Jean Paul), se refiere concretamente a la mecánica teatral empleada por Sánchez: "Nadie lo iguala a esbozar tipos entre cuatro rasgos netos y pintorescos, a modo de esos dibujantes que representan figuras, trazando solamente los contornos; nadie alcanza la intensa visión objetiva de las cosas; su proligidad para el detalle decorativo, su observación fotográfica del fenómeno externo; nadie le gana a representar vivamente cuadros en 'los cuales se agitan docenas de personajes, actuando suelta-

30 En la Iglesia del Cordốn, de Montevideo, está bautizado con el nombre de Florencio Antonio, hijo de Olegario Sánchez y Jovita Musante.

31 De una conferencia pronunciada por Ricardo Rojas, en el Teatro Odeón, de Buenos Aires, en 1911, reproducida como prólogo, en: Florencio Sánchez, Moneda falsa, drama en tres cuadros, Buenos Aires: Editorial Quetzal, 1953. 
mente, en aparente entrevero, pero sin que falle jamás el resorte de su justa y oportuna locomoción".32

Florencio Sánchez nació en Montevideo, el 17 de enero de 1875; murió en Milán (Italia), el 7 de noviembre de I9ro. En los siete últimos años de su existencia escribió veinte cbras teatrales, casi todas estrenadas con éxito ruidoso.

Hasta hace algún tiempo, las dos capitales del Plata se disputaban la paternidad del dramaturgo, y cada una aducía razones igualmente atendibles en su favor. En Montevideo nació y se formó; además, en los últimos años de su vida, había vuelto a residir en la capital uruguaya, oportunidad en que el Gobierno oriental le proporcionó los medios para realziar su anhelado viaje a Europa. En Buenos Aires, adonde llegó a los veintiún años, transcurrió su vida de autor dramático; de su ambiente se nutrió, fundamentamente, la temática de sus principales obras, y allí se consumó su triunfo literario.

Por eso es que el tratadista uruguayo, Alberto Zum-Felde, escribe con ecuanimidad: "Habría, pues, que decir, en rigor de verdad: el teatro argentino del uruguayo Florencio Sánchez. Pero lo más sensato, desde el punto de vista de la historia literaria - por encima de rivalidades vecinales - nos parece considerar a Sánchez como una personalidad pla. tense". Y concluye, perentoriamente: "En vez de ser objeto de mezquina disputa, su nombre ha de trocarse en emblema de comunidad".33

También la figura física de Sánchez es novedosa, dentro de la estructura de típico criollo de la ciudad. Alto, delgado, desgarbado, fácil motivo para caricaturistas. Rostro moreno, aindiado, pómulos salientes, grandes ojos, labios gruesos; cabello liso, negro, largo, peinado en dos haces, que nunca lograba mantener en orden. Con esta estampa y con su natural despreocupación por las frivolidades, no aprendió nunca a llevar la ropa en forma elegante, y vestía como provinciano o como obrero endomingado.

Desde niño vivió en Minas, Departamento del Uruguay, donde hizo estudios primarios, que ya no iba a completar sistemáticamente, cogido por el afán de ganarse el sustento, por su intensa labor teatral y por la vida de bohemia que llevó en Buenos Aires. "No había hecho Sánchez estudios metódicos serios - anota Echagüe - y ni tampoco acaso

32 Juan Pablo Echagüe, Un teatro en formación, Buenos Aires, 1919.

33. Alberto Zum-Felde. Critica de la literatura uruguaya, Montevideo: Editor: Maximiano García [Colección Estudio], 1921, p. 220. 
lecturas eclécticas y razonadas; su mente se formó en redacciones y cenáculos, en lecturas de actualidad, tumultuosas y precipitadas". ${ }^{34}$

A los quince años ya lo vemos intervenir en $L a V o z$ del Pueblo, periódico de Minas, con mordaces y pintorescos artículos contra personalidades locales, cuya pacatería lo sacaba de quicio, especialmente los miembros de la Junta Económico-Administrativa de aquella ciudad, en la que desempeñaba un modesto empleo. Los artículos, naturalmente, los firmaba con pseudónimo. Usó tres, en diferentes épocas: Jack (sin destripador), con que aludía al famoso asesino inglés del momento; luego, Jack the Ripper, Octavio paredes y Luciano Stein.

Separado del cargo en la Junta -como cra de esperar--, toma un empleo en la Oficina de Estadística y Antropometría, recién creada, en la ciudad de La Plata, Argentina, en el año r892. Aquí traba amistad entrañable con un compatriota suyo, de más edad, también empleado en aquella dependencia, Antonio Masoni de Lis, que va a orientarlo ideológicamente hacia el anticlericalismo y la libertad social, 35 y que más tarde, por influencia de teóricos de moda, Bakounine, Kropotkine, Fauré, Malatesta, etc., lo llevará a adoptar una posición tevolucionaria anarquista, que se reflejará en la mayor parte de sus obras.

Por economía se suptime la Oficina de Estadística y Antropometría, y Sánchez de nuevo queda cesante. Vuelve entonces a Montevideo; allí se inicia en el periodismo, en el diario La Razón, donde se ve obligado a afinar sus recursos expresivos y a superar su formación cultural primaria; comienza a tomar contacto con personas de figuración en el campo literario, como el crítico Samuel Blixen, Rodríguez Larreta, Acevedo Díaz, Julio Piquet.

Como es tradicional, las redacciones de los diarios, sobre todo en aquellos tiempos de fronda, eran centros de hervidero de discusiones políticas. Pues de alli Sánchez se incorpora a las filas revolucionarias de Aparicio Saravia, del Partido Blanco, hacia el año ז897, y que preten-

34 Juan Pablo Echagüe (Jean Paul), Seis figuras del Plata, Buenos Aires: Editorial Losada, 1938 , p. 130.

35 En enero de 1893, con motivo del Año Nuevo, Sánchez escribe desde La Plata, a Antonio Masoni de Lis; hay alli un párrafo que corrobora las afirmaciones consignadas: "Termino, pues, enviándole un cariñoso saludo en este día y haciendo votos para que en el año que entra sigan las ideas liberales avanzando a pasos agigantados, siempre abriendo brecha, y veamos finalizar el 93 al clericalismo fanático caído, revolcarse impotente, furioso entre sus babas, en el lodazal inmundo de sus vicios" (La carta íntegra está citada en Fernando García Esteban, Vida de Florencio Sáncbez; con cartas inéditas del insigne dranaturgo, Santiago de Chile: Ediciones Ercilla, 1939 (Vid. Epistolatio, p. 255). 
dían derribar al Presidente Constitucional del Uruguay, Juan Idiarte Borda. En estas tropas participaba también Horacio Quiroga.

Sánchez, escritor incontenible, no podía intervenir sólo con las armas, que en modo alguno eran su especialidad; publica un periódico manuscrito, El Combate, 36 en cuyas páginas, llevado por su espíritu burlón, se reía de cuanto le parecia ridiculo en las filas revolucionarias y sus hazañas algo zarzuelescas. En una de esas chanzas cayó su jefe, de apellido Mena, quien leyó el escrito que aludía a su comportamiento. El soldado Florencio Sánchez fue llamado a su presencia y fue objeto de atroces insultos de parte del afectado. Tal incidente le produjo profunda impresión, y desilusionado del blanquismo, desertó a Sant'Ana, Brasil, cuya frontera estaba a un paso.

Fines de siglo. El ambiente rioplatense está siendo ganado por las ideas socialistas y anarquistas en lo político. En lo literario, Rubén Darío, secundado por Lugones, imponen el modernismo: Florencio Sánchez tomó contacto con Darío, según consta en una carta, aun cuando el poeta nicaragüense no lo mencionara en su Autobiografía. En cuanto a su posición doctrinaria social, Sánchez tenía un espíritu propicio al anarquismo y a los anhelos libertarios algo confusos. En las redaccio. nes de los diarios que frecuentó, como periodista, vivió plenamente ese clima cultural que anunciaba el advenimiento de una centuria cargada de novedades.

En 1898 , es secretario del diario político La República, de Rosario. Deseoso de actuar en la capital argentina, abandona ese cargo y trabaja ocasionalmente en El Páśs y en El Sol, donde usa el pseudónimo de Luciano Stein. Aquí publicó las Cartas de un Flojo, páginas en las que se burla de las revoluciones americanas, de las que él habia huido desencatado, porque las veía como farsas de opereta.

Tanto en Buenos Aires como en Montevideo, había prendido, a fines de la centuria, la semilla de los ideales políticos de avanzada, provenientes del positivismo, de las obras de los teóricos anarquistas y las de Zola. Así fue cómo se formó en Montevideo el Centro de Estudios Intemacionales. En el seno de esa organización se comprendió pronta que el teatro era un excelente medio de acendramiento y de difusión de estas nuevas ideas, y se constituyó un Centro Filodramático para re-

36 El encabezamiento del periódico revela el carácter de esta publicación: julio, 29 de 1897. Campamento en marcha. Año I, $\mathbf{n}^{9} 1$. El combate. Director: Juan el Tano. Secretario de Redacción: Roberto el Diablo. Diario político; noticioso, social. Notá los manuscritos no se devuelven. Suscripción, en la localidad: $\$ 10.00$. En otra parte: nada. 
presentar obras en castellano e italiano, cuyos contenidos coincidieran con los postulados del Centro de Estudios. Pues en ese conjunto dra. mático participó Sánchez, como actor, en ambos idiomas. También para ese grupo escribió su primer ensayo teatral, la comedia en un acto, $L a$ drones, que en 1902, se va a presentar en Rosario, con el título definitivo de Canillita. Dos años más tarde, consolidada ya su fama, a principiós de 1904, la Compañía de Gerónimo Podestá representó la obra en el Teatro Comedia de Buenos Aires; en esta ocasión, el personaje central, Canillita fue interpretado por Blanca Podestá.

Ya en ese primer paso, Florencio Sánchez revela su simpatía y emocionada comprensión hacia los sectores populares, su actitud de protesta social en favor de los suplementeros, en el presente caso, los que desde entonces, en Argentina, se les designa con el nombre de canillitas, y, sobre todo dio una prueba categórica de su dominio del arte escénico. Además, se observa que, dentro del clima obscuro y miserable, aparece, en la escena final, la nota salvadora que contradice el nihilismo típico del espíritu anarquista que se esperaba en el integrante del Centro de Estudios Internacionales, nota de luz que no siempre encontramos en sus obras de mayor vuelo, excepto en La gringa, en la que también queda el horizonte abierto.

Pichín es un maleante que explota y maltrata a su mujer, Claudia, $y$ a su hijo, Canillita. Al final, ha golpeado a su mujer. Canillita salta, en defensa de su madre, cuchillo en mano. Interviene el : vecino don Braulio, hombre bueno, de edad madura, que desarma al muchacho y evita momentáneamente el desastre... Pichín se vuelve contra don Braulio, quien se ve obligado a asestarle una puñalada. Ante tal desenlace, Canillita dice: "Ah, don Braulio...! ¡Me hubiera dejado a mí..."” Don Braulio replica: "Preferible es que acabe yo mis días en un presidio a que empecés los tuyos en una cárcel. ..!"

El mismo año, el Centro Filodramático le estrena el paso de comedia Puertas adentro, en un acto; una sátira violenta contra la moral del matrimonio aparentemente bien avenido.

El I3 de agosto de 1903, Gerónimo Podestá, en el Teatro de la Comedia, de Buenos Aires, estrena M'bijo el dotor, la primera obra de trascendencia de Florencio Sánchez. Ahora el gaucho ha perdido definitivamente todos los arrestos de héroe legendario; ya no se enfrenta a situaciones inverosímiles, tan gratas al espectador primario, que buscaba modelos heroicos; ni el facón homicida ni la persecución injusta y romántica. Tampoco el guitarrón poético ni el pericón tradicional. Pero, 
en cambio, este gaucho ha ganado en humanidad, en autenticidad conforme a la urgencia de mirar las cosas en sus justos límites. Es el hom. bre cabal, con los problemas que plantea un pueblo, cuya estructura comienza a complicarse con el avance de los tiempos. El primer choque entre la ciudad y el campo, entre el progreso cultural y la tradición, entre la civilización que ya inicia, pujante, su dominio sobre la barbarie -el fecundo tópico formulado por Sarmiento en la literatura hispanoamericana-, acarrea graves problemas en el seno familiar. Julio, el dotor, el hijo de campesinos educado en la ciudad, tal vez sorprendido y algo atosigado de filosofias que, por falta de hábito de una raza nueva, no ha logrado asimilar con la debida parsimonia, representa a las generacion nes que inaugurarán el siglo. Se enfrenta a don Olegario, su padre, hombre apegado todavía - como no pudiendo ser de otro modo-a la tierra y a la tradición, a un sistema moral que caducaba, junto con el siglo xIX. Don Olegario es hombre del pasado y sucumbe con él. "No quiero dejar en la ciudad ni los huesos", dice y se viene enfermo a morir al campo. Y Julio: "En el fondo, él no tiene la culpa. ¡Es su tiempo, es su vida, son sus prejuicios. . ! ¿Pretender arrancárselos en estas circunstancias...? ¡Convencerlo...! Llegar junto a su lecho, y decirle: ¡Padre, muérase usted de rabia, pobre espíritu viejo...."'

Es indudable que el esquema de este conflicto está apuntado ya en iAl campo!, de Granada, aunque en forma de comedia. Como lo anotamos más adelante, en Florencio Sánchez va a tener su plenitud de desar trollo.

Sin embargo, Julio no rompe de un modo categórico con el campo. La ciudad no puede prescindir de la tierra. $Y$ este gaucho joven y civilizado, se queda con lo mejor, con lo positivo que el agro puede brindar: Jesusa, de quien pronto tendrá un hijo. "El porvenir decidirá", dice Jesusa. El porvenir está emblematizado en ese vástago que viene, hijo del dotor y de una campesina. El porvenir del pueblo rioplatense es un elemento que no había sido considerado hasta ahora en el teatro, y en $L a$ gringa va a adquirit una forma más concreta.

La obra posee, pues, un rico contenido simbólico y una significación histórica tal, que resume y compendia los tiempos que vive no sólo el ámbito rioplatense, sino todos los pueblos de la América que se despabila frente a la vertiginosa entrada de la centuria.

El estreno de $M^{\prime}$ bijo el dotor reveló de inmediato a un autor cabal, dueño de una técnica eficaz y absolutamente inmerso en una temática nacional $y$ de honda raigambre americana. Este acontecimiento consti- 
tuyó, además, un recuento de los esfuerzos que venían practicándose desde el Moreira, en el sentido de hallar el cauce del teatro autóctono, de formar intérpretes para su justa expresión y de crear un público, con una sensibilidad, receptividad y comprensión del arte nacional. En esta elaboración, es preciso reconocer la importancia que tuvo el cultivo del sainete, por influencia de las compañías españolas, a partir del revistero criolla Miguel Ocampo, en 1890.37

Los hermanos Podestá, cuyo inicio arranca del Moretra, constituyen un factor sustancial en esta configuración del teatro nacional. Primero se destacan José J. Podestá, que interpretó a Juan Moreira, y Gerónimo, que tuvo a su cargo el alcalde don Francisco. Luego, con La piedra de escándalo, de Coronado, en 1902, surge la figura extraordinaria de $\mathrm{Pa-}$ blo, el intérprete de Florencio Sánchez. "Había en ese momento, en el mundo teatral porteño, dos fuerzas poderosas: una, la reciedumbre dramática de Sánchez; otra, la reciedumbre interpretativa de Pablo". 38 La mayor parte de las obras de Florencio fue interpretada por los Hermanos Podestá.

Después de Canillita, Las cédulas de San Juan y La pobre gente, la compañia de Angelina Pagano estrena la segunda obra grande de Sánchez, también de ambiente gauchesco, La gringa. De nuevo la civilización y barbarie, el tópico característico de las letras americanas, campea en esta pieza gauchesca, la definitiva del utor, según firma Ricardo Rojas.

Los tres elementos estructurales son aquí el viejo Cantalicio, símbolo de la tradición primaria, de una conformación espiritual apegada a los añejos métodos culturales y de trabajo, sin miraje al futuro, cada día más deslumbrante que se insinúa. Por el otro lado, aparece Nicola, el gringo emigrado, piamontés, que trae la nueva pujanza, y que con su esfuerzo tenaz y el de su familia -al mismo tiempo que introduciendo un nuevo concepto del trabajo productivo- se va adueñando honradamente, de los terrenos que Cantalicio no trabaja. El tercer elemento lo constituye la pareja joven de Próspero, hijo de Cantalicio, y Gloria, hija de Nicola, expresión del feliz y fecundo maridaje de las dos razas. Sánchez sintetiza aquí otro de los momentos primordiales de la formación del pueblo rioplatense.

La República Argentina, y junto a ella la Uruguaya, experimenta

37 Luis Ordaz, prólogo a Siete Sainetes Porteños, Buenos Aires: Ediciones Losange [Colección Teatro Argentino, $\left.\mathbf{n}^{\circ} 4\right], 1958$, p. 10.

38 Angela Blanco Amores, "Pablo Podestá. El gran trágico y el drama nacional", Boletin de Estudios de Teatro, Instituto Nacional de Estudios de Teatro, Año VI, tomo VI, $\mathbf{n}^{9} 20-21,1948$, p. 20. 
un rápido crecimiento, a contar del último cuarto del siglo pasado; la actividad económica en sus múltiples aspectos, se manifiesta en las nuevas industrias, en el desarrollo del comercio y en el trabajo de la tierra. Este proceso se acelera con el ingreso al país, en 1889, de más de doscientos cincuenta mil inmigrantes, de diversas procedencias y razas, principalmente españoles e itálianos. La abundancia de estos últimos dio una conformación muy acusada a la psicología del argentino, a su idioma y hasta a su estructura somática. En un principio, la expresión gringo llegó a ser sinónimo de italiano, como gallego, de español. "El inmigrante se adapta o no, pero a su vez, impone un nuevo sentido a las. cosas". .39

La mayor parte de estos europeos se incorporó a los grandes centros poblados, como Buenos Aires. De aquí es que se produjo la mezcla y la asimilación profunda, que alentó y vigorizó la base autóctona de manera notable, situación que no se dio en Chile, con la inmigración alemana de mediados de siglo, que se radicó en el Sur y formó una colonia hermética.

En el momento en que Sánchez estrena La gringa no habian transcurrido quince años de la aportación étnica europea de fondo; por lo tanto recién se estaba operando la amalgama ítalo-platense, y sus proyecciones eran vagamente previsibles. Sin embargo, para el dramturgo, tales efectos aparecian rotundos, como puede verse en la escena final de la obra: Cantalicio y las huestes de su caduca tradición sucumben, o quedan a la zaga, con una impotente protesta patriotera o sentimental. Horacio, el joven, ingenuo, formado en Buenos Aires, hijo de Nicola, dice, viendo a Próspero y Victoria: "iMire qué linda pareja...! Hija de gringos puros..., hijo de criollos puros...! de aquí va a salir la raza fuerte del porvenir..."

Próspero tiene clara conciencia de la cuestión desde hace tiempo; en las primeras escenas del acto primero responde a un peón: "Amalaya nos fuéramos juntando todos los hijos de criollo y de gringo; verían qué cría...."

Próspero es la buena base criolla, sin la obsecación infructuosa de un amor irracional a un pasado que ha de superarse; es la Argentina sana, virgen y con la mirada puesta en un porvenir claro. Su mente está limpia de aquellas teorias a medio deglutir, que confundian a Julio, el dotor. Próspero es el sentido de la tierra, de la América que as-

39 Luis Ordaz, ob. cit., p. 8. 
pira a ser fecundada en su generosa entraña, la América que abre sus puertas al progreso del siglo $\mathrm{xx}$.

Cantalicio, como don Olegario, se ha quedado a la zaga, apegado al ombú legendario y a un vacío hermetismo patriarcal.

En La gringa queda perfectamente deslindado que no se trata de una entrega de la tierra al extranjero y de una negación de la eficacia del nervio americano; sino que de una fecundación de razas, de una aportación recíproca: los buenos hábitos de pueblos experimentados y acendrados por una larga tradición y el vigor del criollo americano. Queda establecido también la gran lección de confraternidad y de entendimiento entre grupos humanos que podrian haberse reputado hetrogéneos. Andando el tiempo, la República hermana va a mostrar esa pujante vitalidad que vaticinó la intuición de Sánchez, en su desarrollo cultural y económico de gran potencia sudamericana.

En cuanto a la construcción dramática, La gringa presenta un desarrollo gradual nítido de todos los elementos en juego, en forma tal que al espectador - en el caso de Sánchez hay que hablar decididamente de espectador más que de lector-ve, de manera gráfica, la penetración de los aportes piamonteses en el ambiente criollo y su paulatina sustanciación. Ya en las primeras escenas, Nicola aparece con el motivo del tratamiento que debe darse a los animales. Un peón ha castigado a una bestia porque "es muy mañera". Nicola se ha indignado: "¿Se ha pensado--dice al peón-que las yeguas son hombres..., y que comprenden las cosas cuando les pegan?". Luego, más adelante, sorprende que otro de los trabajadores ha perseguido a una liebre, y que seguramente lo ha hecho con su cabalgadura; otro estallido aleccionador: " $; \mathrm{Ah}$, canalla! Has andado cansando la yegua, eh!"

En seguida, el motivo del estoicismo, expresado en Rosina, chica de diez o doce años. A la par que los mayores, Rosina se ha levantado al alba, en el crudo invierno santafesino. Regresa con los demás, al desayuno. Viene con una mano ensangrentada y se urga la herida con la punta de un cuchillo. Copiemos la escena, tan plena de elementos identificadores de los extranjeros:

Victoria. Bueno, vamos a tomar café, que mamá está enojada... Vení Luiggin... Pasa... (Mutis de Nicola y Luiggin). ¿Y Rosina? (Llamando) ¡Rosina!

Rosina. ¡Aquí estoy!... Esperate un poco...

Victoria. ¿Qué hacés? (Se aproxima a la cbica, y al ver la sangre, 
da un grito). Muchacha... iQué has hecho! Dios mío...

Rosina. Nada... Una astillita. En la mancera del arado, al hacer así... Me la clavé.

Victoria. ¡Oh, qué barbaridad...! ¡Virgen Santísima!

Nicola. (Reapareciendo) ¿Qué pasa? ¿Qué gritos son ésos!

Victoria. Esta pobre chica... Dios Santo.

Nicola. (alarmado) ¡Cosa! ¿Cosa! (Examina la mano de la cbica y con gesto displicente) ¡ $\mathrm{Ba}$ ! Zoncerías... ¡No es nada! Zoncerías... iVení a tomar el café...!

Rosina. ¡Eso digo yo! Una pavada... (Se pasa la lengua sobre la berida $y$ bate mutis con Nicola y Victoria).

Se ve claro que la niña ha trabajado con el arado, labor pesada hasta para un hombre. Luego, no atribuye importancia a un trastorno que estima natural en las faenas campesinas. Cualquier alharaca sobre ello es una pavada. Su padre ha dicho zonceria. En cambio, Victoria, a pesar de pertenecer a esta misma raza, algo dura - de gringos desal. mados, los califica un peón que comenta la escena-es más sensitiva, más femenina, más maternal, rasgos que enajenan de inmediato la sim. patía del espectador y la distingue en medio de esa familia que sentimos hecha de una sola pieza. Victoria es el puente de plata, como Horacio, el hijo ingeniero, entre las dos recias tradiciones.

Una vez planteada la lucha entre gringos y criollos, esperamos - como ha sido nuestro hábito, si no desde la Conquista, al menos de la Revolución de la Independencia-que triunfen, regocijadamente, los nuestros, como ocurría con Martín Fierro y Juan Moreira, cuando éstos batían a la partida. Pero, al oír a Nicola, en los inicios de la pieza, aludir a su hijo, "ése que estudia en Buenos Aires", y que le "ha demandado que le busque tierra, porque quiere venir a poner una granja de cremería...", entonces sentimos que en esta batalla no podremos llevar la mejor parte. Sentimos la presencia de un tipo de contienda distinto, que nos induce a respetar a un adversario que plantea la lucha en un plano complejo y superior. Vemos, pues, que Nicola no es un simple oportunista y acopiador de dinero: su impulso es profundo y generoso y, sobre todo, potente, porque se sustenta sobrę bases inobjetables. De lo contrario, habría dejado a Horacio trabajando en el campo, privado de los estudios universitarios. Nicola no envía a su hijo a una Universidad europea, sino que cree en la eficacia de la Universidad criolla, lo que constituye un nuevo y demoledor golpe para quienes no ha- 
bíamos reparado en la importancia trascendental de ese centro de cultura, $o$ en el cual sencillamente no teníamos fe.

Con este estilo de pelea no podia competir el espíritu de Cantalicio, ni el de Olegario. Tampoco podía hacerlo con buen éxito, don Zoilo, de Barranca abajo.

Nicola es un hombre progresista, sin duda. No viene sólo a "hacer la América". No; él viene a radicarse para siempre, dispuesto a integrarse a esta tierra y a su destino. Pero no se incorpora como un parche, pasivamente, en la mecánica rutinaria --inercia y herencia de una España medieval, caballeresca, romántica y feudal-, sino que impone sus categorias, una nueva forma de vida; estatuye, en fin, su sóldio empuje ancestral - que es también inercia y herencia de otros mandantes-con el concepto del progreso del siglo XIX.

Naturalmente que tales propósitos debían encontrar resistencias contumaces, en las que fácilmente podía entrar en juego un mal entendido patriotismo. El único que ubica en sus verdaderos términos el problema es Próspero, que simboliza, por cierto, a los vastos sectores de criollos inteligentes. $Y$ como para que tal comprensión se revele más honda, vital y trascendente, aparece el signo del amor, abierto hacia horizontes ilimitados, de prosperidad y gloria. Desde un principio, el joven gaucho intuye las ventajas de esta nueva manera de concebir el mundo y de hacer las cosas. Sin romper los lazos de afecto con su padre - porque no se trata de volver la espalda a un pasado secular y borrarlo, como lo pretendian los personajes arribistas de ; Al campol, y también el engreído Julio, de $M^{\prime}$ 'bijo el dotor-adhiere plenamente al bando de los aparentes tivales de su progenitor, a trueque de granjearse la malquerencia suya.

Tampoco el joven se entrega, deslumbrado, al dominio del patrón extranjero, como, por necesidad o por subestimación personal lo hace el peón, dado ya a su hábito de explotado, sino que entra a participar, como un factor primordial, en la nueva sociedad.

Todo este alegato está contenido sustancialmente en $L \bowtie$ gringa, pero sólo en el subtexto, en el carácter de los personajes, en las situaciones, en el conflicto y en el desenlace. Florencio Sánchez, revolucionario gestado en un medio romántico-anarquista, de confusas aspiraciones sociales, no ha caído en la peroración y las reflexiones discursivas. $Y$ este es uno de los méritos inamovibles de la pieza extraordinaria. De tales debilidades suelen resentirse otras composiciones del autor, como Nuestros bijos, por ejemplo, y Los derechos de la salud, en las que se produce 
el divorcio entre los valores estéticos intrínsecos y el mensaje, lo que no da lugar a la vibración vitalizadora de toda obra teatral.

Cantalicio es, incuestionablemente, un personaje de tragedia. Se dan en él los elementos de una necesidad incontrastable que gravita sobre su destino; su personalidad irradia conmiseración y terror. Se cumplen las condiciones de lo trágico en el personaje y en el acontecimiento. ${ }^{40}$

Sánchez lo sintió así, sin duda, porque muy pronto, cinco meses después del estreno de la obra comentada, pone en escena Barranca abajo (26 de abril de 1905), en donde Cantalicio recibe un enfoque más directo y categórico, en el doloroso don Zoilo. Aparece aquí, dignificado por la desgracia, víctima de manejos tinterillescos, formas diabólicas que puede asumir el poder de la ley. A esta corrupción del sistema vigente, se suma la corrupción de su propia familia, también contaminada por los males imperantes, desintegrada por la inmoralidad de los inescrupulosos. Es una etapa natural -y transitoria-en la evolución que está experimentando el ambiente nativo, llamado y exigido por los nuevos tiempos a tomar parte activa en el desenvolvimiento económico del país. Los criollos han aprendido la técnica de adueñarse legalmente de lo ajeno, de las tierras principalmente, de aquellas tierras dormidas de la pampa, y que no consiguieron despertar Esteban Echeverría, ni Sarmiento, ni Alberdi. Los leguleyos se apoyan en disposiciones de una legislación romántica que no podía prever fácilmente los excesos que podía permitir una aplicación dolosa, por funcionarios venales y sin miramientos.

El gaucho viejo, rezagado en su desarrollo de productor, que no ha logrado hacerse cacique, que con su economía mezquina y tarda no establecía relaciones de compadrazgo con las autoridades locales, caía atrapado, sin darse cuenta cómo, por aquellos tentáculos ávidos e invisibles, hasta "perder el campo en que ha trabajado toda la vida, y la hacienda y todo! Porque dejuramente, entre jueces y procuradores, le han 'comido vaquistas y majadas" (Acto I, esc. IV).

La obra no alude, ahora, a la inmigración, aun cuando, en gran medida, pudiera ser uno de los factores que han promovido el nuevo estado de cosas. Al autor le interesa otra perspectiva del problema; los

40 Además de la indispensable Poética, de Aristóteles, vid: Henri Gouhier, La obra teatral, Buenos Aires: Editorial Universitaria de Buenos Aires [Eudeba], 1961 , pp. 171-172; Wolfgang Kayser, Interpretación y análisis de la obra literaria, Madrid: Editotial Gredos, 1954, p. 594-597. 
efectos que estos trastornos han producido en el seno mismo de la familia criolla.

La última escena del acto primero deja claramente establecida la cuestión general. Han venido a casa de don Zoilo-que ya no le pertenece-don Luis, triunfador del pleito y pretendiente ocasional de Prudencia, la hija mayor del paisano, y el comisario Gutiérrez, galán de la Rudecinda, hermana del gaucho.

Zoilo. ...Como le iba diciendo, usted sabe que esta casa y este campo fueron míos, que los heredé de mi padre, y que habían sido de mis agüelos... ¿no? Las vaquitas y ovejitas esistentes en el campo, el pan de mis hijos, las crié yo a juerza de trabajo y sudores, ¿no es eso? Bien saben todos que con mi familia fue creciendo mi haber, a pesar de que la mala suerte, como la sombra al árbol, siempre me acompañó.

Luis. No sé por qué viene eso, francamente.

Zoilo. Un día... Déjeme hablar. Un día se les antojó a ustedes que el campo no era mío, sino de ustedes, metieron ese pleito de reivindicación, yo me defendí, las cosas se enredaron, como herencia de brasilero, $y$, cuando quise acordar, amanecí sin campo, ni ovejas, ni techo, para amparar a los míos.

Luis. Pero usted bien sabe que la razón estaba de nuestra parte.

Zoilo. Taría, cuando los jueces lo dijeron; pero yo dispués no supe hacer saber razones que yo tenía.

Luis. Usted se defendió muy bien, sin embargo.

Zailo. (Alzândose terrible). No, na me defendí bien, no supe cumplir con mi deber. ¿Sabe lo que debía hacer, sabe lo que debía hacer? Buscar a su padre, a los jueces, a los letraos, juntarlos a todos ustedes, ladrones, y coṣerles las tripas a puñaladas, pa escarmiento de bandoleros y saítiadores. ¡Eso debía hacer! ¡Eso debía hacer! ¡Coserlos a puñaladas!

Algunos estudiosos, basados en expresiones del personaje, han destacado la maĺa suerte como uno de los leitmotiv de Barranca abajo Creemos que tal recurso de apoyatura debilitaría la idea central del autor. El hombre del pueblo, acosado por desgracias provenientes de la necesidad de las circunstancias conflictivas, atribuye a esa causa incontrolable sus. descalabros. En la pieza, es verdad, hay una reminiscencia 
de la clásica posición del gaucho fatal frente a la injusticia de las autoridades. Pero la causa real reviste mayor macicez, si atendemos a la línea creadora que viene desarrollando Florencio Sánchez: el choque entre el espíritu viejo que se abate ante las nuevas formas culturales, que por el momento buscan su cauce y su ajuste. No es, pues, la mala suerte que se ensaña con un individuo o con una familia, tomados al azar, como el fatum de los Atridas de la tragedia griega. Es un estado crítico que afecta a todo un caduco modo de vivir.

En esta lucha, el paisano viejo pierde también a su familia que, desbaratada por la miseria, se entrega a la concupiscencia de los patrones. $\mathrm{Y}$ don Zoilo queda absolutamente solo. Vencido, solo y viejo, como hombre y como institución. El vecino Zoilo Carbajal, "aura es el viejo Zoilo, como dicen todos".

Entiende claramente su posición en el mundo. $Y$ se quita la vida, resignado.

La trilogía gauchesca de Sánchez - M'bijo el dotor, La gringa y Barranca abajo-que sin duda constituye la culminación de ese teatro criollo rioplatense que venimos diseñando, fue magníficamente complementado con sus pinturas de ambiente arrabalero de Buenos Aires. Entre esas producciones, merece destacarse como modelo la comedia de tema hampón, Moneda falsa, en tres actos, estrenada por la compañía de Gerónimo Podestá, el 8 de enero de I907. También incursionó en los sectores de la clase media, con el mismo buen éxito; prueba de ello es su drama de tipo ibseniano, scbre el alcoholismo, Los muertos, "una de las piezas más depresoras que of rezca a la sensibilidad contemporánea", según afirmaba Ricardo Rojas, en I9Ir.

A instancias de otros famosos uruguayos, entre ellos Rodríguez Larreta y Rodó, a la sazón díputados, el Gobierno del Uruguay, bajo la Presidencia de Claudio William, le confiere una modesta pensión, por dos años en Italia, con lo que Florencio Sánchez ve cumplirse uno de sus más sentidos anhelos. Parte con ese destino, viaje del que no debia regresar vivo, en septiembre de I909. Allí, por sus acostumbrados descuidos y por falta de atención, se agrava su mal, la tuberculosis, que parecía haberlo llevado en latencia, durante muchos años. Después de soportar miserias y penurias, tan dramáticas como sus obras más grises, muere en Milán, asistido por el rosarino Santiago Devic y el Cónsul uruguayo en esa ciudad italiana, Bernardo Callorda. Sus restos mortales fueron repatriados a Montevideo, en enero de I92I, ceremonia que al- 
canzó relieves de homenaje nacional, y en la que intervinieron ambas márgenes del Plata. ${ }^{41}$

Entre sus papeles quedaron en proyecto o a medio escribir, tres obras: La plebe, drama en cuatro actos; El derecho a la tristeza, drama en tres actos, y La viudita, comedia.

El itinerario gauchesco, rematado tan exitosamente en Florencio Sánchez, abrió una ancha visión sobre los temas, personajes y problemas vernáculos, confirió prestigio a esos materiales de escenificación y estimuló a escritores e intérpretes nacionales.

No es extraño, entonces, que un hombre como Gregorio de Laferrère (1867-I913), de actividades tan ajenas a los tablados - a no ser su inquietud de espectador y lector-se sintiera, de la noche a la manana, impulsado a escribir teatro y a obtener en la empresa un triunfo indiscutible. El primer oficio de Laferrère fue la política. Su claridad mental de estirpe francesa, su mesura y elegantes maneras, ganadas en el seno de una familia acomodada, lo habian premunido de agilidad mundana, aplomo y simpatia personal, para campear con soltura en lides electorales. Fue diputado provincial y nacional, una figura de brillo en las tertulias de club, sólidamente relacionado en los círculos culturales del Buenos Aires del 900; asiduo asistente a estrenos teatrales, especialmente a las presentaciones de las comedias de los Hermanos Alvarez Quinteros, cuya influencia en sus obras es notoria.

¿Cómo llegó a hacerse escritor dramático un hombre que parecía más destinado al foro parlamentario o a la tertulia diplomática?' ¿Cómo pudo ingresar tan limpiamente a la cerrada órbita teatral sin parecer un advenedizo?

El mismo ha aclarado este punto en un reportaje, algunos de cuyos fragmentos consigna José María Monner Sans, en el Apéndice de las Obras escogidas, de Lafarrère." "Escribi mi primera comedia por humorada-dice-, sin imaginarme que alguna vez sería llevada a las tablas". Ricardo Rojas, en La literatura argentina (Los modemos, II), refiere que esta primera obra, ilettatore...', nació como producto de una amistosa apuesta. Asistía a una representación y emitió un juicio adverso acerca de ella. Su amigo, Beazley, que lo acompañaba, le expresó

41 Sobre los patéticos días finales de la vida de Sánchez, véase: Fernando Garcia Esteban, Vida de Florencio Sánchez, Santiago de Chile: Ediciones Ercilla, 1939 , pp. 229 y ss., y Wilfredo Jiménez, Pasión de Florencio Sáncbez, Biografía dramatizada, en tres actos, Buenos Aires: Ediciones Losange, 1955.

${ }_{42}$ Gregorio de Lafferrère, Obras escogidas, prólogo y notas de José María Monner Sans, Buenos Aires: Angel Estrada y Cía., S. A., Editores, 1943, 330 pp. 
que era más fácil criticar desde la platea, que crear. Lafertère contestó que le probaría lo contrario y que escribiria, a corto plazo, una come. dia superior a la que presenciaban. $Y$, efectivamente, en pocos días turo listos los borradores de iJettotore...!

En el reportaje mencionado, explica su actitud ante el arte escénico. "Un día me hizo gracia el teatro: eso es todo. $\mathrm{Y}$ como, por hábito, hago siempre lo que me causa placer, hice teatro..., y lo haré cuantas veces se me ocurra, sin preocuparme de otra cosa que de mi propia satisfacción. No pretendo, pues, estar contribuyendo con mi grano de arena a echar los cimientos de nuestro teatro. No me debe el teatro nacional ni desvelos, ni esfuerzos, ni sacrificios. En cambio, le soy deudor de algunos buenos momentos de mi vida".

Estas palabras ponen de manifiesto su personalidad que, aunque no sean sinceras y encierren un propósito más polémico que expositivo de una verdad, revelan al humorista de honda vena. ¡Qué distancia lo separa del gauchismo trágico o doliente! Como una compensación, surge "el gran conductor de la risa porteña", según la expresión de Vicente Martínez Cuitiño. En efecto, todas sus obras, exceptuando el drama Bajo la garra, son comedias en que campea la gracia liviana y el humor tras el cual suele esconderse una sátira nada piadosa contra la sociedad bonaerense de principios de siglo.

Laferrère, hombre de la ciudad, conocedor del complejo mundillo social de su patria, y provisto de antecedentes extranjeros observados en su viaje a Europa, en su juventud, incorporó al teatro rioplatense el elemento urbano de la clase media. "Las obras de Lafarrère y de sus coetáneos-anota Monner Sans- señalan la declinación de la dramática gauchesca y la lenta urbanización de nuestro teatro".

iJettatore...!, fue estrenada por la Compañia de mayor cartel de la época y que estaba cumpliendo un brillante papel en este florecimiento del teatro argentino; era el conjunto de Gerónimo Podestá. E1 acontecimiento tuvo lugar el 3 I de mayo de $x_{904}$. "Los del gremio-escribía Enrique García Velloso-aguardaban la première con cierta conmiseración burlona". Pero el triunfo fue inobjetable; la obra alcanzó las setenta y cinco representaciones consecutivas.

La pieza desartolla el tema de la superstición. El jettatore, don Lucas en la comedia, es un personaje a quien se le asignan influencias misteriosas y maléficas sobre sus semejantes, sin que él se proponga irradiar su maleficio. Todo su ambiente gira en función de ese aciago poder, que le ha sido impuesto por los mismos que se consideran sus 
víctimas. La obra organiza jocosamente las mil incidencias que emanan de la jettatura, con un dominio del género, propio de un veterano en ell oficio.

Era una sátira oportuna, porque "aquel Buenos Aires - dice Monner Sans-padecía la pueril preocupación del mal de ojo". Esta inquietud morbosa, influencia del campo sobre la ciudad, habia sido intensificada por los inmigrados italianos, que habían aportado, además del término jetta, cábalas, amuletos y exorcismos.

Justamente un año después, el 6 de mayo de 1905 , la Compañía de Podestá estrena la segunda comedia de Laferrère, Locos de verano. Otro vicio colectivo, producto de los nuevos tiempos, que el autor describe en una estampa de vertiginosa agilidad.

Hay una disposición en la energía creadora del autor, que viene de la periferia al centro. al núcleo mismo de la burguesía rioplatense que se configura aceleradamente. iJettatore...!, representa una transición entre el teatro popular y el teatro urbano, porque esa primera comedia, aunque puesta en un medio más culto, contiene el elemento popular: la superstición. En Locos de verano, se ha afinado esa dirección en el ahondamiento del análisis de una manía específica de una sociedad ganada ya por las complejidades del siglo. El tema es el afán coleccionista o la especialidad intrascendente.

En una atmósfera de familia acomodada, de clase media, circula una treintena de personajes, representantes de todos los matices de la gama social bonaerense, de principios de la centuria. Cada uno viviendo su vida, entregado a su interés absorbente. Sofía consume su existencia dedicada a coleccionar postales y autógrafos; Pepe escribe dramones y sueña con llegar a ser un Shakespeare; Tito es esclavo de su máquina fotográfica y de su fonógrafo, con el que intermitentemente quebranta los nervios de los demás; Elena sólo está interesada en su figuración en sociedad y en los periódicos locales que pueden aludir a su manía; Arturo es jugador y maquina estafas cada vez que la ocasión le es propicia o cada vez que siente apremios; Severo aspira a acertar en la lotería, al mismo tiempo que explota las manías de los demás; don Ramón Gómez, el dueño de casa, es cerrado adicto al gobierno y vive atento a la chismografía política; etc. Los únicos personajes cuerdos de la obra son Enrique Gómez, que no entiende ese mundo de disparatados, y Lucía, piadosa y comprensiva. El juego, como es de esperarlo, termina con la vuelta a los cauces del buen criterio.

Aqdemás de la oportuna advertencia contra los prematuros síntomas 
monomaníacos de un siglo que se anuncia agitado, la comedia contiene otro valor de mayor dimensión señalado de paso por Monner Sans, en el prólogo mencionado: "...se anticipa a señalarnos el aislamiento de cada ser, recluso en su hermético yo". Efectivamente, se anticipa en varios decenios, al menos dentro del proceso artístico americano, a una visión de la soledad en que vive inmerso el hombre, y que va a ser una de las tonalidades constantes en todas las expresiones creadoras de posguerra. En la Argentina, dentro del plano teatral, habrá que esperar el advenimiento de Samuel Eichelbaum, y en la narrativa, a Eduardo Mallea y Jorge Luis Borges, para ver planteado en todo su despiadado rigor, el problema de la incomunicabilidad de los seres humanos, a pesar de los a priori afectivos de los fenomenologistas; en Chile, esta concepción característica de los últimos decenios está representada en la segunda etapa de la producción literaria de la novelista Marta Brunet. 43

Otro año justo y Lafarrère estrena, ahora, un drama, Bajo la garra, a fines de mayo de 1906. Abandona, por un momento, la modalidad jocosa y enfoca en un tono didáctico serio, el tema de la maledicencia social. Aprovecha más detenidamente su conocimiento directo del ambiente mundano de club, con personajes elegantes. Su propósito en esta obra, como en todas las demás, es "fustigar el vicio que lo mancha todo cuando adquiere los contornos de una verdadera deformidad social", según palabras del propio autor. Una especie calumniosa circula y acusa injustamente a Elena, víctima propiciatoria de la indiscreción, la exageración y la perversidad de espíritus ociosos.

Pero la obra que le ha granjeado fama imperecedera en el Continente es la comedia Las de Barranco, estrenada en abril de 1908, por Orfilia Rico. Muchos son los méritos que explican su calidad de pieza clásica americana, de comedia casi perfecta. La escatimación alude al remate de la obra, algo descuidado. Mas, examinaremos sus innegables valores que, a nuestro juicio, bastarían para ubicar a Laferrère dentro de las figuras más notables del teatro hispanoamericano.

Veamos primero el asunto. Doña María, viuda del capitán Barranco, con una modesta pensión del Estado, debe mantener a sus tres hijas, Carmen, hermosa, atractiva y discreta; Manuela, preocupada de moños y composturas, y Pepa, pequeña fierecilla indomada. Doña Ma-

423 Véase nuestro breve estudio "Marta Brunet, puente de plata hacia el Sur", Anales de la Universidad de Cbile", Santiago de Chile: Año CXIX, $n^{\prime 2} 124$, cuarto trimestre de 1961, pp. 80-94. 
ría debe hacer toda clase de figuras para subsistir con su familia, subarrienda dos cuartos de la casa que ella ocupa, uno a Morales, estudiante de Medicina, y otro a Eduardo Linares, escritor. Además, y éste es el motivo trágico y cómico central, explota el interés de varios pretendientes de Carmen de quienes consigue regalos y otros servicios; hasta el recaudador del alquiler, al que adeuda ya varios meses, obtiene prórrogas, of reciéndole esperanzas de entendimiento con su hija Carmen. Ha llegado a crearse una técnica de sutil extorsión: halaga al pretendiente en nombre de Carmen, y si el casu lo exige, requiere la presencia de la niña, a quien obliga con miradas y gestos amenazantes disimulados, a colaborar en su plan. Sin embargo, ni Carmen tiene interés en estos galanes, ni doña María desea que se case, porque "casándose Carmen se concluye el filón y la casa se derrumba". La llegada de Linares crea el problema sentimental. A pesar de que "la voluntad brutal de la madre concluye por dominarla siempre", esta vez Carmen, hastida y asqueada, termina por irse del hogar, con Eduardo Linares.

Este es el esqueleto de los cuatro bien llevados actos. Incorpora dos elementos importantes al teatro argentino: el estudio de caracteres femeninos y la clase media baja, la clase del gurango, es decir, aquel matiz que en Chile llamamos medio pelo.

"La escena representa un vestíbulo guarangamente amueblado", dice la acotación del autor. Una página luminosa del ensayista y dramaturgo Ezequiel Martínez Estrada, en Radiografía de la pampal, nos aclara el concepto de este estrato social, mezcolanza en que no son ajenos los ingredientes gauchescos, urbanos y de inmigrados:

"Aunque se le encuentra en pleno centro, el guarango es típico de los arrabales del centro de la cuidad. Puede verse en él al gracioso sin cultura, al actor que improvisa sin genio, resentido de alguna privación de que es culpable mucha gente. No está satisfecho de su suerte con su papel auténtico, y busca una compensación mediante la mortificación de los demás". "Es incivil, basto, sin pulimentos y desgastes que la sociedad impone a la pantamima del hombre". "El guarango también quiere ser protagonista; ser persona importante que atraiga la atención" (Buenos Aires, Losada, r942, t. II, PP. 26-28).

Son algunos de los caracteres básicos de doña María y de los pretendientes de Carmen, y corresponden a la atmósfera mezquina y sórdida, sin llegar a la miseria, que alienta en casa de las de Barranco. Carmen es un individuo de excepción; hay en ella delicadeza, nobleza y, sobre todo, pasión, atributos de alto vuelo, ausentes en los demás. Mo- 
rales y Eduardo Linares no son guarangos, poseen el afinamiento que les confiere su formación cultural, pertenecen a la casta de Carmen, y por ello, entienden la abrumadora posición de instrumento que le ha impuesto su adverso destino de venida a menos. Morales, secreto enamorado de la joven, abandona su íntima e inconfesada inclinación, y deja el campo expedito a la pareja Carmen-Linares.

Laferrère exhibe en esta comedia una mezcla de todo lo risible del guarango, estridente y superficial, junto a las trágicas limitaciones culturales y éticas de su condición. Además, hay un enjuiciamiento a los invisibles responsables de la miseria de todo un vasto sector de la socicdad bonaerense.

Después de Florencio Sánchez, el tema del gaucho crudo viene a menos. Ya se habían fijado los moldes de su condición primaria, de su evolución, de la toma de conciencia de su papel en las nuevas formas culturales y hasta de las deformaciones de su esencia. El gauchismo élemental se sostiene difícilmente en el uruguayo Ernesto Herrera (El león ciego, I9II), y en los argentinos Julio Sánchez Gardel (La montaña dé las brujas, I9I2) y Carlos Schaefer Gallo (El giacbo judio, I912); a estos nombres habría que agregar a Yamandú Rodríguez, con El mathera y a Justino Zavala Muniz, con La cruz de los caminos.

Los tiempos cambian. El realismo-naturalismo ha completado su ciclo y cede paso a las tendencias expresionistas o al simple psicologismo. Buenos Aires se convierte rápidamente en una ciudad cosmopolita; es el principal centro de contacto de Europa con la América del Sur; sólo hasta allí se aventuran las compañías extranjeras de espectáculos; la inmigración espontánea es continua. Desde el punto de vista económico, los países del Viejo Mundo que se aprestan a la primera gran conflagración, ven a la zona rioplatense como una rica y segura base de abastecimientos.

En ese clima, era natural que la mentalidad del público y de los autores se dejara influir por los temas de carácter universal y de análisis interior, y el gauchismo doméstico perdiera terreno.

El advenimiento, primero, y el cultivo, después, de la zarzuela y del sainete, géneros eminentemente urbanos, aunque populares, terminan por atraer la atención hacia temas de ambiente orillero, lógica transición entre el campo y la ciudad.

Este paso bacia 2 interior las esencias del gauchismo bárbaro ganadas definitivamente por las complejidades de la civilización está, a 
muestro juicio, claramente señalado en la obra entera de Samuel Eichelbaum (I894), producto de las nuevas corrientes estéticas de posguerra.

Laferrère todavía permanecía ligado de algún modo a la tonalidad popular y al tratamiento especial, pintoresco, en que los sucesos se desenvuelven ampliamente, con manifiesta gravitación del ambiente. Eichelbaum, en cambio, inaugura otro modo dramático, de contención de análisis hondo y pormenorizado, en donde los personajes adquieren relieve psíquico monstruoso, y se debaten en angustiosa lucha consigo mismos. Tal actitud explica que las obras de este autor estén pobladas de seres que parecen vivir una vida de más alto nivel cultural. Aún en comedias campesinas o arrabaleras, como El páfjaro de barro, El gaapo del $900 \mathrm{y}$ Un tal Servnado Gómez, los individuos razonan con un rigor no solamente lógico, sino éticamente superior, de tal manera que dentro de los moldes del realismo-naturalismo ya periclitado, resultaría chocante y falso.

El autor se impone conscientemente la norma; se propone presentar, en cada obra, una idea, a través de un personaje sustlanirializado, ejemplar provisto de un concepto que trasmite integro, con eficacia, al intelecto del espectador, más que a su afectividad, hermetismo que, diremos de paso, explica la discreta difusión que han gozado las obras de este autor. Así construye personajes únicos, que vemos desenvolverse en obsesionante soledad, dentro de sí mismos, como no teniendo semejantes. Ejemplar en su soltería itremediable es Eleuterio, transido y anquilosado por la soledad infiltrada a su médula por sus hermanas, de El gato y su selva, I936; ejemplar, en su alto concepto del honor, de estirpe calderoniana, el matón de caudillo político, Ecuménico López, de Un guapo del 900, I940; lo es la china, Felipa, convencida instintivamente de la crisis de la institución matrimonial como factor progenitor, pero elevando a la categoría de valor absoluto la calidad de madre, que para tal efecto no requiere la concurrencia de un padre, de El pájaro de barro, 1940, y los esposos Morrison, símbolos de la avaricia y del poder psicológico del dinero, de Las dos brasas, I955, brasas que se queman y consumen a sí mismas, y Servando, el esposo y padre por excelencia, con un hijo de otro, de Unt tal Servando Gómez, I942.

El guspo del 900, estrenada en 1940, representa el último alarde del entronque con Martín Fierro y Juan Moreira, los guapos clásicos del teatro criollo. El personaje es característico en las campañas políticas hispanoamericanas de tipo caudillesco, formas que vienen siendo superadas paulatinamente, y en especial después "de la segunda guerra, por luchas activadas sobre partidos organizados y principios doctrinarios. 
El guapo está al servicio de un cacique político, con su cuchillo y el prestigio de su fama de malevo, capaz de movilizar una pandilla en escaramuzas delictuosas en apoyo de un candidato.

El término guapo posee una connotación idealizadora del personaje; en Chile, en cambio, se dice matón o mardito o amarditao, con un sentido evidentemente peyorativo. El guapo, pues, sigue siendo el héroe popular, romántico, apolitizado, sin una clara orientación ideológica social, de raigambre gauchesca. Así lo señalan rasgos como su destreza en el manejo del cuchillo, su antagonismo indiscriminado al orden policial, su individualismo exacerbado, al mismo tiempo que su valentía y machez, su exaltado sentimiento del honor, la lealtad a la palabra empeñada, su sentido humano y su tierno amor a la familia, factores todog que el caudillo explota en favor de sus propósitos.

El guapo del 900 posee una significación de suma y cierre de un trabajado proceso: estructuración de una raza nueva y formación de un teatro nacional sobre bases autóctonas.

Es, pues, un digno homenaje tributado a las tradiciones populares más estimadas del gaucho, quintaesenciadas en la personalidad de un espécimen colocado en el pórtico inquietante de un nuevo siglo; Ecuménico sintetiza en gran relieve las mejores energías útiles del alma gaucha, aprovechables en empresas superiores que han de empeñarse en las luchas y conquistas que se avecinan.

La obra es, por último, el símbolo de la búsqueda de los instrumentos teatrales capaces de expresar la absorción profunda, lenta e inexorable que ha venido realizando la civilización desde las bárbaras formas del matrero.

Julio DuRÁn Cerda

Universidad de Chile. 